\title{
PENINGKATAN KAPASITAS KOMPETENSI BAHASA JEPANG DASAR DAN PROMOSI WISATA PELAKU PARIWISATA DESA KEMENUH, KECAMATAN SUKAWATI, KABUPATEN GIANYAR
}

Lien Darlina ${ }^{1}$, Ni Made Sudarmini², Solihin ${ }^{3}$

${ }^{1}$ Politeknik Negeri Bali

${ }^{2}$ Apoliteknik Negeri Bali

${ }^{3}$ Politeknik Negeri Bali

darlina@pnb.ac.id ${ }^{1}$,madesudarmini@pnb.ac.id ${ }^{2}$, solihin@pnb.ac.id ${ }^{3}$

Submited : 09 July 2020 | Acepted :29 July 2020| Published : Desember 2020

\begin{abstract}
Abstrak
Peningkatan kapasitas kompetensi bahasa Jepang Dasar dan peningkatan Promosi Wisata Desa Kemenuh bagi para Pelaku Pariwisata di Desa Kemenuh, Kecamatan Sukawati, Kabupaten Gianyar mutlak diperlukan. Kedua aspek ini sangat penting untuk mendukung industri wisata alam, seni dan budaya yang sekarang sedang berkembang dengan baik dan merupakan ikon pariwisata di daerah tersebut. Dari pengamatan yang dilakukan masih adanya hambatan-hambatan dalam pengelolaan berbagai potensi wisata, terutama tentang promosi wisata alam, seni budaya dan kebahasan yang dihadapi oleh pelaku pariwisata Desa Kemenuh pada saat berkomunikasi verbal dengan wisatawan asing. Oleh karena itu, petani di daerah ini yang sekarang bergeser menjadi pelaku pariwisata perlu dilatih kemampuan promosi dan kemampuan bahasa asing untuk melayani para wisatawan asing tersebut. Metode pembelajaran yang digunakan berbasis paradigma student centered dengan pendekatan communicative language teaching yang bertujuan untuk meningkatkan kompetensi komunikasi bahasa Jepang dengan cara mengenalkan suatu konteks yang relevan. Peserta setelah diberikan pelatihan sudah mampu mengucapkan bunyi 'hatsuon', greetings, asking thanking and saying apologies, serta bercakap-cakap: memperkenalkan diri, menyatakan kepunyaan, menyampaikan angka (pemakaian nomor telepon), menyampaikan skejul ( jam, hari, tanggal, bulan dan tahun), menjelaskan harga, menjelaskan posisi dan letak suatu benda dan menyampaikan aktifitas dalam tingkatan Bahasa Jepang Dasar.
\end{abstract}

Kata Kunci: SME dengan produk kerajinan tangan, eco-produk, pemberdayaan ekonomi 


\section{PENDAHULUAN}

Desa Kemenuh berada di Kecamatan Sukawati, Kabupaten Gianyar, Bali. Desa tersebut dapat dikategorikan sebagai desa menengah. Sumber daya desa dan potensi yang dimiliki bertumpu pada empat sektor yaitu: pertanian, kerajinan, seni dan pariwisata. Desa ini mempunyai arti strategis sebagai penyangga kota Gianyar masih menonjol suasana tradisional yang dikuatkan oleh fungsi lembaga-lembaga kemasyarakatan seperti: Desa pakraman, Subak, Banjar, Sekaa Teruna dan yang lainnya. Dengan adanya moderisasi yang ditandai dengan geliat Pariwisata telah membuka akses lokal, nasional sampai ke tingkat mancanegara.

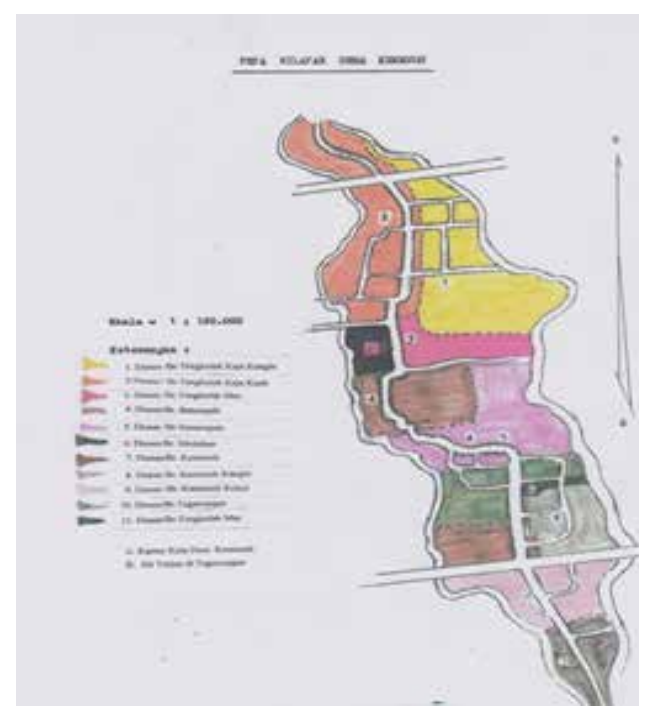

Gambar 1 Orbitasi Desa Kemenuh

Desa Kemenuh pada dasarnya memiliki beragam potensi dan bahkan keunggulan lokal. Lokasi desa sangat strategis, sehingga potensi sumber daya seni perkembangannya paling menonjol. Citra positif desa tentang kerajinan patung kayu dan daya tarik pariwisata budaya dengan adanya air terjun di Tegenungan, cycling, Rumah Topeng dan Wayang Setyadharma, Kemenuh Butterfly Park, Kampus seni dan lembaga tradisional yang lainnya. Desa Kemenuh sejak awal tahun 1930an telah berkembang sebagai daerah wisata dimana saat ini desa ini menjadi salah satu desa wisata di Bali dengan peringkat 10 di tingkat nasional dan Kelompok Sadar Wisata (Pokdarwis) Juara III seni budaya di tingkat nasional. Seni Budaya Desa sebagai potensi lokal desa dikembangkan untuk menjawab tantangan yaitu untuk pemenuhan daya tarik wisata yang lain dengan Kawasan Air Terjun di Banjar Tegenungan Desa Kemenuh.
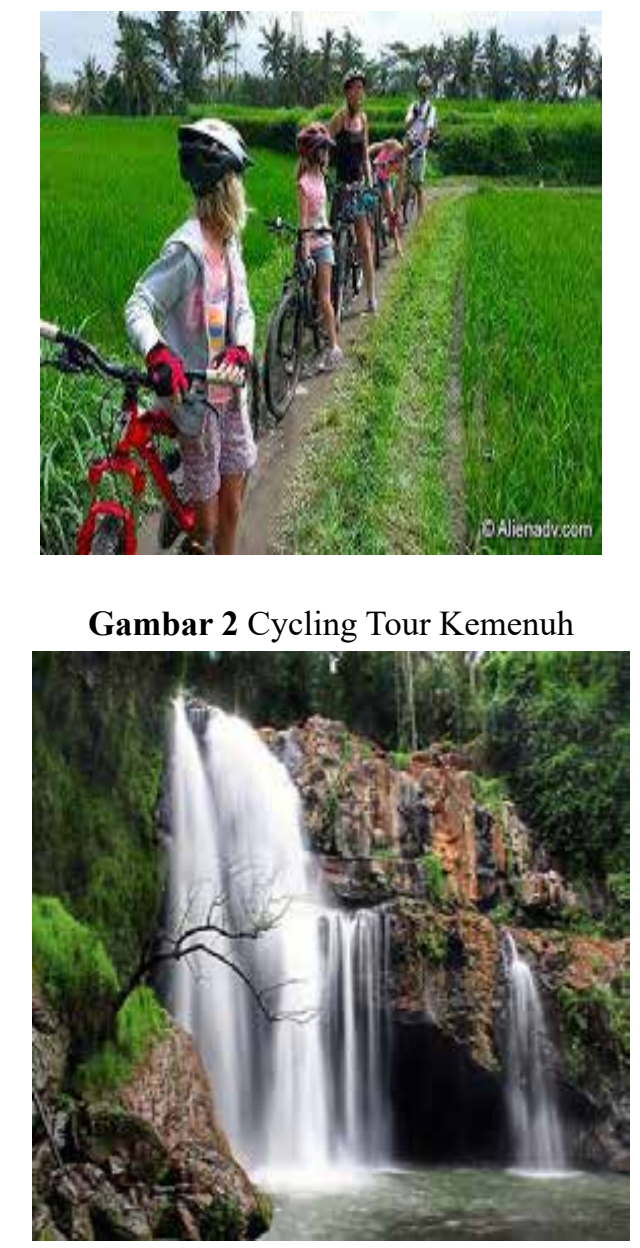

Gambar 3 Waterfall (Air terjun) Tegenungan 
Keberadaan industri pariwisata, di Desa Kemenuh, Kecamatan Sukawati, Kabupaten Gianyar sangat penting dan merupakan salah satu sumbangan yang sangat berarti dalam meningkatkan perekonomian masyarakat yang menjadi pendapatan asli daerah (PAD) kabupaten tersebut. Sumbangan yang lain dalam bidang ekonomi adalah: (1) menyediakan lapangan kerja untuk mengurangi pengangguran dan urbanisasi; (2) membangkitkan semangat masyarakat para petani dan pengrajin. Sedangkan sumbangannya dalam pelestarian alam adalah: (1) menumbuhkan dan meningkatkan minat masyarakat dalam memelihara lingkungan sungai, lahan pertanian, dan memberdayakan masyarakat dalam mewujudkan industri pariwisata yang ramah lingkungan dan berkelanjutan (green and sustainable technology); (2) ) mempertahankan dan melestarikan eksistensi budaya masyarakat setempat.

Jurusan Pariwisata Politeknik Negeri Bali sebagai lembaga pendidikan vokasi mengamati perkembangan pariwisata di Desa Kemenuh, Kecamatan Sukawati berkembang sangat pesat, baik kedatangan wisatawan nusantara maupun kedatangan wisatawan manca negara dengan berbagai aktivitasnya. Oleh karena itu kemampuan komunikasi masyarakat yang tadinya sebagai petani dan pengrajin dan sekarang bergeser menjadi pelaku pariwisata harus diimbangi dengan kemampuan bahasa asing untuk meningkatkan pelayanan kepada para wisatawan asing tersebut. Selain itu, untuk meningkatkan kunjungan wisatawan, mereka harus diberikan pengetahuan tentang promosi wisata terutama promosi wisata yang berhubungan dengan layanan langsung.

Keberhasilan pembelajaran bahasa asing, termasuk pembelajaran Bahasa Jepang ditunjukkan oleh salah satu dari beberapa indikator yaitu kompetensi komunikatif (kemampuan seseorang untuk menggunakan bahasa target dengan baik). Kompetensi komunikatif sangat tergantung pada kemampuan pragmalinguistik (penguasaan gramatika bahasa asing) dan sosio-pragmatik (penggunaan bahasa asing sesuai konteks) (Leech, 1983).

Penelitian ini bertujuan untuk mendeskripsikan seberapa efektif dan bermanfaat sistem pembelajaran dengan menggunakan pendekatan komunikatif, jika diterapkan kepada peserta pelaku pariwisata pada kegiatan pengabdian. Metode pembelajaran yang dipakai pada pelatihan ini adalah pendekatan komunikatif. Sesuai dengan karakteristik metode ini, yakni pertama, memusatkan pada fungsi bahasa, bukan pada struktur bahasa. Kedua, dimulai dari analisis kebutuhan peserta, pemilihan materi ditekakan pada topik kegiatan melayani tamu sehingga tidak hanya sekedar membahas struktur kalimat. Hal penting lainnya adalah teknik latihan yang mendukung keberhasilan metode pendekatan komunikasi ini adalah dengan menggunakan penugasan, pemakaian informasi rumpang (information gap) dan roleplay dengan kegiatan bermain peran, simulasi dan lainnya. Hasilnya sangat memuaskan untuk level Bahasa Jepang Dasar, jika dilihat dari hasil post-test yang dicapai.

Tantangan terbesar pada pelatihan kali ini 
adalah karena berada pada masa pandemi. Oleh karena itu pelatihan yang harusnya diselenggarakan pada bulan Mei, baru dilaksakan pada bulan Juni akhir. Meskipun demikian pelatihan berjalan dengan lancar dengan mamatuhi protokol kesehatan. Tentunya hal ini disebabkan karena masyarakat menyadari sepenuhnya perlunya pelatihan bahasa asing, khususnya Bahasa Jepang. Masyarakat Desa Kemenuh yang sudah lama berinteraksi dengan tamu manca negara merasakan pentingnya mampu berkomunikasi Bahasa Jepang.

\section{TINJAUAN PUSTAKA}

Keberhasilan pembelajaran bahasa asing, termasuk pembelajaran Bahasa Jepang ditunjukkan oleh salah satu dari beberapa indikator yaitu kompetensi komunikatif (kemampuan seseorang untuk menggunakan bahasa target dengan baik). Kompetensi komunikatif memuat beberapa komponen, seperti kompetensi gramatika, pragmatik, wacana, strategi, serta kompetensi organisasional (Hymes, 1972; Canale, 1983; Calce-Murcia, Marianne, 1995). Semakin tinggi tingkat kompetensi komunikatif pembelajar, maka mereka dianggap semakin berkompeten dalam memahami bahasa asing. Kompetensi pragmatik sebagai salah satu komponen penting dibedakan menjadi dua, yaitu kemampuan pragmalinguistik (penguasaan gramatika bahasa asing) dan sosio-pragmatik (penggunaan bahasa asing sesuai konteks) (Leech, 1983).

\section{METODE PENELITIAN}

Metode yang digunakan dalam melaksanakan kegiatan pelatihan dalam Peningkatan Kapasitas Kompetensi Bahasa Jepang Dasar dan Promosi Wisata Pelaku Pariwisata Desa Kemenuh, Kecamatan Sukawati, Kabupaten Gianyar, Bali yakni dengan melalui pelatihan bahasa Jepang praktis dengan pendekatan komunikatif atau communicative language teaching. Pembelajaran bahasa Jepang berbasis pada paradigm student centered, yaitu aktivitas pedagogis befokus pada siswa bukan guru. Jadi pembelajaran bahasa asing ini dititik beratkan pada kemampuan bahasa sebagai komunikasi khususnya yang berhubungan dengan pariwisata sesuai lingkungan pelaku wisata berada. Sementara itu, penanganan kepariwisataan khususnya untuk memaksimalkan layanan kepada wisatawan, tidak hanya mengandalkan kemampuan bahasa, tetapi perlu diimbangi dengan humanisme pelaku wisata itu sendiri, maka pada kegiatan ini juga diberikan materi etika pelayanan pariwisata. Selain itu, diberikan juga pengetahuan tentang promosi wisata terutama promosi wisata yang berhubungan dengan layanan langsung, tujuannya adalah untuk meningkatkan kunjungan wisatawan

\section{HASIL DAN PEMBAHASAN}

Kegiatan pelatihan Bahasa Jepang Dasar, promosi pariwisata dan Etika Pelayanan terlaksana dengan lancar. Pelatihan dilakukan setiap hari Senin, Rabu dan Jumat, seminggu tiga kali, dimulai dari bulan Juni 2020 sampai dengan bulan Agustus. Lokasi pelatihan 
dilaksanakan di ruangan pertemuan Balai Desa Kemenuh, Gianyar.

Kegiatan diikuti oleh 15 orang peserta. Kegiatan pelatihan dipandu oleh dosen Bahasa Jepang Promosi Wisata dan Etika Pelayanan Jurusan Pariwisata Politeknik Negeri bali. Materi ajar yang diberikan dikumpulkan dalam bentuk modul yang menarik dan mudah dipahami. Metode yang digunakan dalam pelatihan adalah model pembelajaran langsung, dengan teknik bermain peran dan demonstrasi. Pelatihan dilakukan selama lima belas (lima belas ) kali pertemuan di mulai pada bulan Juni 2020 sampai dengan bulan Agustus. Durasi pelatihan masing-masing dilakukan selama dua jam pada setiap pertemuan. Fokus dari kegiatan pengabdian ini adalah untuk meningkatkan kemampuan komunikasi dan pelayanan terhadap tamu serta berbagai hal yang berkaitan dengan penggunaan bahasa Jepang. Pelaksanaan kegiatan pengabdian diawali observasi, pretest dan penyusunan modul pelatihan serta dilanjutkan dengan kegiatan pelatihan Bahasa Jepang, Promosi Wisata, dan Etika Pelayanan.

Kegiatan dan materi ajar yang disampaikan seperti yang diterapkan pada sub-bab berikut ini.

\subsection{Pertemuan Pertama}

Materi yang diajarkan pada pertemuan pertama adalah pengucapan dalam bahasa Jepang 'hatsuon' mulai dari bunyi a sampai pyo. Dilanjutkan dengan pengenalan aisatsu yang meliputi: greetings, asking thanking, and saying apologies berikut dijelaskan juga bagaimana cara meresponnya.
Media yang dipakai untuk melatih pengucapan 'hatsuon' adalah rekaman bunyi pengucapan Bahasa Jepang, yang dilengkapi dengan rekaman greetings, asking thanking and saying apologies. Latihan ini selain melatih pendengaran juga dapat dipakai dalam mempraktekkan pengucapan greetings, asking thanking and saying apologies tersebut. Pertemuan diawali dengan memberikan pretest kepada para peserta.

\section{Pertemuan Kedua}

Materi yang diajarkan pada pertemuan kedua adalah memperkenalkan kalimat bertanya: nama, status (pekerjaan), dst. Dan dilanjutkan dengan berlatih saling bertanya.

\section{Pertemuan Ketiga}

Materi yang diajarkan pada pertemuan ketiga yakni bertanya nomor telepon dan mengkonfirmasinya. Pembelajar dibekali pemakaian angka dari 0 sampai 10. Untuk melatih komunikasi dan pendengaran pemakaian angka digunakan worksheet dengan saling bertanya nomor telepon. Latihan ini bermanfaat dalam meningkatkan dua kemampuan yakni komunikasi dan pendengaran.

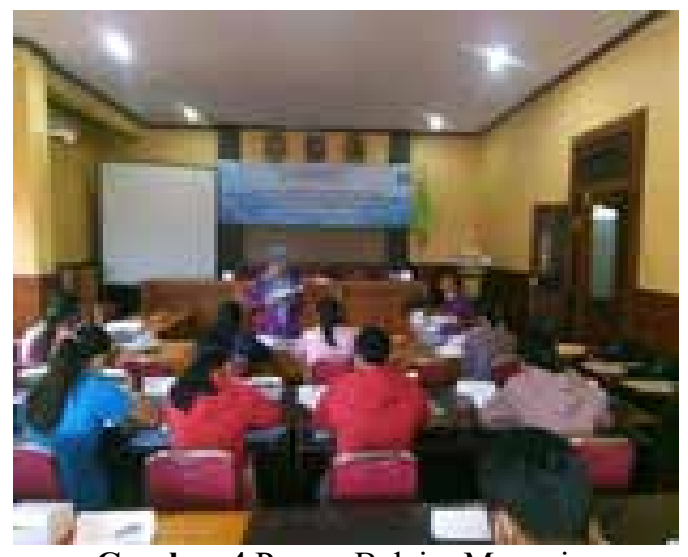

Gambar 4 Proses Belajar Mengajar 
HUMANISM Vol.1 No. 3 Desember 2020

\section{Pertemuan Kelima}

Materi yang diajarkan pada pertemuan keempat adalah menyampaikan kepunyaan, dan nama-nama benda. Peserta dilatih saling bertanya dengan menggunakan kalimat yang menyatakan kepunyaan.

\section{Pertemuan Kelima}

Materi yang diajarkan pada pertemuan keenam adalah pemakaian keterangan waktu jam dan menit. Materi pada pertemuan ini fokus menyampaikan mulai dan berakhirnya kegiatan. Contoh: menjelaskan kegiatan breakfast di restoran (untuk peserta yang bekerja di restoran), memandu cycling menjelaskan jam berapa mulai kegiatan, dan seterusnya.

\section{Pertemuan Keenam}

Materi yang diajarkan pada pertemuan keenam adalah melanjutkan pemakaian keterangan waktu yang menyatakan lamanya, misalnya menjelaskan lamanya untuk cycling, lamanya perjalanan dari hotel ke air terjun, dan seterusnya.

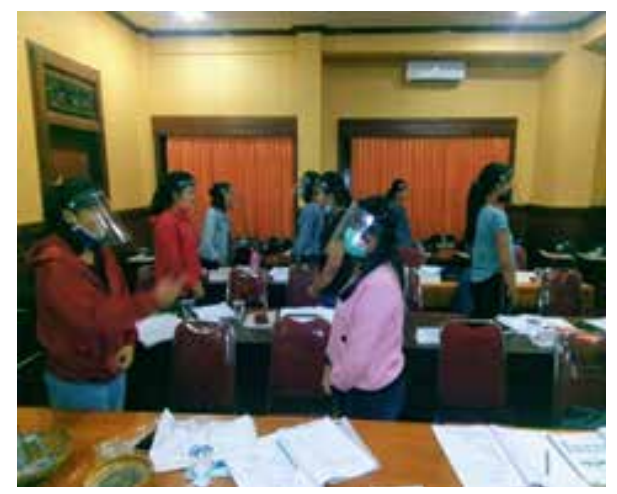

Gambar 5 Role Play

\section{Pertemuan Ketujuh}

Materi yang diajarkan pada pertemuan ketujuh adalah pemakaian keterangan waktu nama hari, tanggal dan bulan. Latihan percakapan yang menggunakan keterangan waktu: tanggal, hari dan bulan yaitu yang berhubungan dengan pemesanan, baik pemesanan kamar, kegiatan pariwisata.

Kegiatan pelatihan dimulai dari praktek pengucapan tanggal, hari dan bulan sampai hafal dan benar pengucapannya.

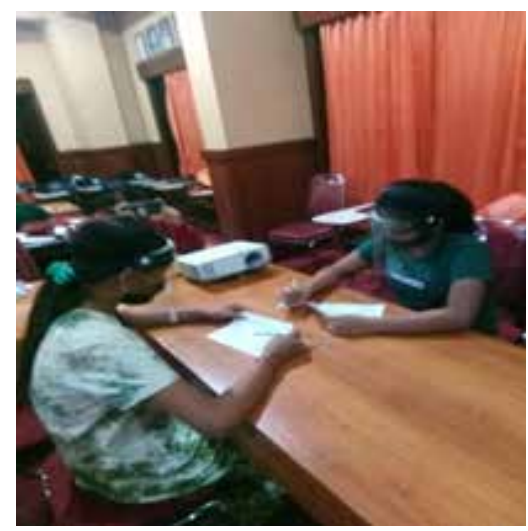

Gambar 6 Latihan Informasi Gap

\section{Pertemuan Ketujuh}

Materi yang diajarkan pada pertemuan ketujuh adalah menjelaskan harga yang terkait dengan kegiatan pariwisata, di antaranya room rate dan tiket masuk ke waterfall atau cycling. Pembelajar dibekali dulu dengan cara menghitung sampai juta.

\subsection{Pertemuan Kedelapan}

Materi yang diajarkan pada pertemuan kedelapan adalah melanjutkan pemakaian angka yakni menjelaskan rate nilai tukar mata uang, contoh nilai tukar dari mata mata uang Yen ke Rupiah. 


\section{Pertemuan Kedua Belas}

Materi yang diajarkan pada pertemuan kesembilan adalah menghandle pembayaran, baik yang pakai: cash, rupiah ataupun yen.

\section{Pertemuan Kesepuluh}

Materi yang diajarkan pada pertemuan kesepuluh adalah Promosi Wisata yakni pentingnya promosi dalam dunia pariwisata

\section{Pertemuan Kesebelas}

Materi yang diajarkan pada pertemuan kesebelas Belas adalah Etika Pelayanan, yakni : halhal yang harus diperhatikan dan dipraktekkan terkait : atitude, smile, knowledge (disingkat A.S.K)

\section{Pertemuan Kedua Belas}

Melaksanakan kegiatan Post-test, dilanjutkan dengan tes praktek percakapan.

Hasil dari pelatihan ini semua peserta tampak antusias dalam mengikuti pelatihan. Hal ini terlihat ketika para peserta diminta bermain peran selalu semangatmeskipun bahasa Jepangnya masih terbata-bata. Rasa percaya diri untuk mempraktekkan percakapan bahasa Jepang sangat tinggi dikarenakan sadar akan perlunya kompetensi/kemampuan berbahasa Jepang pada kegiatan pariwisata. Antusias tersebut dapat dilihat dari perkembangan nilai pre-test dan post-test berikut ini:

Tabel 1. Nilai Pre-test

\begin{tabular}{|c|c|c|c|c|}
\hline No. & NAMA & $\begin{array}{l}\text { TATA BAHASA } \\
(\text { (BUNPOO) }\end{array}$ & $\begin{array}{l}\text { PENGUCAPAN } \\
(\text { HATSUON })\end{array}$ & $\begin{array}{l}\text { PERCAKAPAN } \\
(K A I W A)\end{array}$ \\
\hline 1. & Ni Wayan Yosi & 55 & 40 & 40 \\
\hline 2. & $\begin{array}{l}\text { Ni Made Leoni Purnama } \\
\text { Dewi }\end{array}$ & 55 & 40 & 40 \\
\hline 3. & I Gusti Ayu Iman Mentari & 50 & 35 & 35 \\
\hline 4. & Ida Ayu Putu Okti Intan C. & - & - & - \\
\hline 5. & Ni Made Jesi Viryani & 35 & 30 & 30 \\
\hline 6. & Mekar (kuliah) & 35 & 30 & 30 \\
\hline 7. & Ni Wayan Nahoki Agustina & & - & - \\
\hline 8. & $\begin{array}{l}\text { Ni Komang Esther Trisna } \\
\text { Dewi }\end{array}$ & 30 & 30 & 30 \\
\hline 9. & Ni Kadek Dipa Pradnyani & - & - & - \\
\hline 10. & Ni Wayan Widiantari & - & - & - \\
\hline 11. & Gst Ayu Nym Puspita Hati & 30 & 40 & 40 \\
\hline 12. & Desak Putu Trisna Saptari & - & - & - \\
\hline 13. & Dewa Ayu Sintya Dewi & 30 & 45 & 45 \\
\hline 14. & Dewa Ngakan Putu Tio & - & - & - \\
\hline 15. & I Wayan Adi Prayoga & - & - & - \\
\hline
\end{tabular}


HUMANISM Vol.1 No. 3 Desember 2020

Tabel 2. Nilai Post Test

\begin{tabular}{|c|c|c|c|c|}
\hline No. & NAMA & $\begin{array}{l}\text { TATA BAHASA } \\
(\text { BUNPOO) } \\
\end{array}$ & $\begin{array}{l}\text { PENGUCAPAN } \\
(\text { HATSUON) }\end{array}$ & $\begin{array}{c}\text { PERCAKAPAN } \\
(K A I W A) \\
\end{array}$ \\
\hline 1. & Ni Wayan Yosi & 86 & 80 & 80 \\
\hline 2. & $\begin{array}{l}\text { Ni Made Leoni Purnama } \\
\text { Dewi }\end{array}$ & 85 & 86 & 85 \\
\hline 3. & I Gusti Ayu Iman Mentari & 85 & 83 & 85 \\
\hline 4. & Ida Ayu Putu Okti Intan C. & 82 & 85 & 85 \\
\hline 5. & Ni Made Jesi Viryani & 78 & 80 & 80 \\
\hline 6. & Gusti Ayu Mekar Sari & 70 & 70 & 75 \\
\hline 7. & Ni Wayan Nahoki Agustina & 80 & 78 & 80 \\
\hline 8. & $\begin{array}{l}\text { Ni Komang Esther Trisna } \\
\text { Dewi }\end{array}$ & 80 & 80 & 80 \\
\hline 9. & Ni Kadek Dipa Pradnyani & 78 & 80 & 80 \\
\hline 10. & Ni Wayan Widiantari & 75 & 76 & 76 \\
\hline 11. & Gst Ayu Nym Puspita Hati & 80 & 85 & 85 \\
\hline 12. & Desak Putu Trisna Saptari & 75 & 78 & 80 \\
\hline 13. & Dewa Ayu Sintya Dewi & 78 & 80 & 80 \\
\hline 14. & Dewa Ngakan Putu Tio & 70 & 80 & 78 \\
\hline 15. & I Wayan Adi Prayoga & 73 & 78 & 80 \\
\hline
\end{tabular}

Hasil dari pelatihan Bahasa Jepang Dasar sesuai dengan harapan. Hal ini terlihat dari perkembangan nilai yang dicapai oleh peserta meningkat. Pada waktu pretest peserta kebanyakan tidak tahu tentang pengucapan 'hatsuon', greeting dalam bahasa Jepang. Ada beberapa peserta yang sudah belajar Bahasa Jepang, tetapi masih sangat minim, baik pemahaman grammar ataupun percakapannya.

Pada penilaian tahap berikutnya post-test kemampuan peserta dalam berkomukasi Bahasa Jepang terlihat sudah terbiasa mengucapkan dan mempraktekkan percakapan bahasa Jepang. Dapat dilihat dari hasil test, kemampuan peserta baik pada grammar, kaiwa 'percakapan' dan hatsuon 'pengucapan' hasilnya sangat bagus. Kemampuan peserta meningkat seperti terlihat pada tabel di atas. Para peserta selain belajar bahasa Jepang (sebagai pelatihan utama), mereka diberi juga pelatihan promosi pariwisata dan etika pelayanan. Mereka diajari bagaimana cara mempromosikan pariwisata ketika berhadapan dengan tamu supaya tamu datang kembali berkunjung ke Bali, atau juga mempromosikan Bali ke keluarga atau teman-temannya. Kedua pelatihan tersebut, baik Bahasa Jepang ataupun promosi tentunya digunakan untuk melayani tamu mancanegara, sehingga pelatihan etika pelayanan bermanfaat bagi peserta.

\section{KESIMPULAN}

Kegiatan pelatihan Bahasa Jepang Dasar, promosi pariwisata dan Etika Pelayanan terlaksana sebanyak lima belas kali pertemuan. Pelatihan yang diikuti oleh lima belas orang peserta ini menggunakan metode pembelajaran langsung dengan teknik bermain peran dan demonstrasi. Materi ajar yang diberikan dibukukan dalam bentuk modul yang menarik dan mudah dipahami. Sebelum melaksanakan 
pelatihan peserta mendapatkan pre-test untuk mengukur pengetahuan awal peserta. Setelah pelatihan berakhir, peserta diberikan posttest untuk mengetahui sejauh mana efektifitas metode yang diberikan. Pelatihan telah berhasil meningkatkankemampuan peserta dalambahasa Jepang dibuktikan dari hasil post-test mereka. Selama pelatihan, Semua peserta juga tampak antusias dalam mengikuti pelatihan. Pelatihan promosi pariwisata dan etika pelayanan diajarkan dengan cara mempromosikan Bali ke keluarga dan teman-teman serta ke wisatawan. Kedua pelatihan tersebut bermanfaat bagi peserta untuk melayani tamu mancanegara, sehingga pelatihan etika pelayanan bermanfaat bagi peserta.

\section{DAFTAR PUSTAKA}

(2015). Desa Kemenuh, Gianyar, Menuju

Desa Pariwisata Berbudaya. http://infopublik.id/read/79015/ desa-kemenuh-gianyar-menujudesapariwisataberbudaya.html

Bachman, L. F., \& Palmer, A. S. (2010). Language assessment in practice: Developing language assessments and justifying their usein the real world. Oxford University Press.Canale, M (1983). "From Communicative Competence to Communicative Language Pedagogy". I J. C. Richard \& R.W. Schmidt (Eds), Language and communication (pp.2-27). London: Longman.

Calce-Murcia, Marianne, Z. D. and S. T. (1995). Communicative Competence: A Pedagogically Motivated Model With Content Specification. Issuses in Applied Linguistics, 6(2), 5-35.
Canale, M. (1983). From Communicative Competence to Communicative Language Pedagogy Language and communication (I J. C. Richard \& R.W. Schmidt (ed.); Language a). Longman.

Damanik, Janianton dan Weber, Helmut. (2006). Perencanaan Ekowisata Dari Teori ke Aplikasi.Yogyakarta: PUSPAR UGM dan Andi

Hymes, D. (1972). On Communicative Competence Sociolinguistics (J. Pride, J. B., Holmes (ed.); Sociolingu). Pinguin.

Leech, G. (1983). Principles of pragmatics. Longman.

Takimoto, M. (2009) The effects of input-based tasks on the development of learners' pragmatic proficiency. Applied Linguistics,30/1, 1-25.

Widanta, I.M.R.J., et al. (2018). TaskBased Language Teaching: How it is implemented effectively?

Yoeti, Oka A. (2008). Perencanaan dan Pengembangan Pariwisata, cetakan kedua.PT. Pradnya Paramita. 